\title{
THE COMMUNICATIVE GRAMMAR TRANSLATION METHOD: A PRACTICAL METHOD TO TEACH COMMUNICATION SKILLS OF ENGLISH
}

\author{
Kaharuddin \\ Univeristas Islam Negeri (UIN) Alauddin Makassar \\ andi.kaharuddin@uin-alauddin.ac.id
}

\begin{abstract}
This paper is theoretically aimed at discussing how to teach communication skills (written and spoken) through a combination between the classic grammar translation and the modern communicative language teaching). The combination not only results in the formation of a new method which is here known as the communicative grammar translation method, but also in the formation of a new methodology in English language pedagogy which might be applied by English teachers to teach communication skills in the classrooms. The methodology of this new method consists of three special procedures i.e. The first is structural procedure which allows the learners to learn grammar rules and vocabulary. The second is transitional procedure which gives opportunity to the students to practice using the rules in translation and pronunciation drills. The third is communicative procedure which also gives the learners opportunity to use their knowledge of grammar and vocabulary in communicative activities. The implementation of the three procedures is believed able to achieve three learning outcomes i.e. making the learners able to deliver English basic communication both in spoken and written, promoting the learners' language accuracy and fluency in communication, and improving the learner knowledge of grammar and vocabulary to enhance initiatives in communication.
\end{abstract}

Keywords: teaching method, grammar translation method, communicative grammar translation, communication skills,

\section{A. INTRODUCTION}

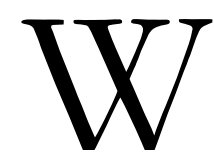

hen The Grammar Translation Method comes into the area of language teaching method, we will soon recognize that the grammar-translation method has become the child nobody loves or wants to acknowledge since this method has been considered out of date and ineffective to be used in modern language teaching. This tendency can obviously be seen if we do a quick search through the internet for "grammar-translation method," we'll immediately notice something striking on some definitions given to The Grammar Translation Method says that The Grammar Translation Method is an old method which was originally used to teach dead languages. Actually, dead languages in the definition refer to Latin and Greek which were learnt to uncover information and to get access into the history of ancient civilizations. Orrieux, C. (1989) states that Latin and Ancient Greek are known as "dead languages", based on the fact that people no longer speak them for the purpose of interactive 
communication. Yet they are still acknowledged as important languages to learn (especially Latin) for the purpose of gaining access to classical literature, and up until fairly recently, for the kinds of grammar training that led to the "mental dexterity" considered so important in any higher education study stream. In addition, Morris, S. (1996) is of the opinion that Latin has been studied for centuries, with the prime objectives of learning how to read classical Latin texts, understanding the fundamentals of grammar and translation, and gaining insights into some important foreign influences Latin has had on the development of other European languages. The method used to teach it overwhelmingly bore those objectives in mind, and came to be known as the Classical Method. It is now more commonly known in Foreign Language Teaching circles as the Grammar Translation Method.

The statements above have obviously given a recent status to The Grammar Translation Method as the Old Fashioned Method or Classical Method. Consequently, this method is ignored by mostly second/foreign language instructors and gets a really bad rap in the ESOL (ESL, EFL) world. According to Richards and Rodgers, the grammar-translation has been rejected as a legitimate language teaching method by modern scholars. They further state that though it may be true to say that the Grammar-Translation Method is still widely practiced, it has no advocates. It is a method for which there is no theory. There is no literature that offers a rationale or justification for it or that attempts to relate it to issues in linguistics, psychology, or educational theory. Besides, The Grammar Translation Method is felt to contribute many disadvantages such as: 1). The Grammar Translation Method may make the language learning experience uninspiring and boring, 2). The Grammar Translation Method may also left the students with a sense of frustration when they travel to countries where the studied language is used (they can't understand what people say and have to struggle mightily to express themselves at the most basic

level), 3). This method neither approaches nor encourages the students' communicative competence. Of course, the disadvantages of GTM are identified from the teaching principles of this method.

\section{B. LITERATURE REVIEW}

\section{Pros and Cons Of The Grammar Translation Method}

Despite the grammar-translation method is not widely adopted in language teaching nowadays. However, hybrid forms of the method can be found in some places. According to Jack 
Richards and Theodore Rogers (2001) in their book, Approaches and Methods in Language Teaching, this method is still used in some countries but has been rejected by most educational scholars. Based on Richards and Rogers' statements, we can recognize the existence of pros (for those who still adopt GTM) and cons (for those who reject GTM) upon The Grammar Translation Method.

At least, there two major reasons for some language teachers still using the Grammar Translation Method i.e. reasons related to the pedagogical process (practical reason) and the assessment process (procedural reason). From the pedagogical process point of view, the method is still considered to be effective used for teaching owing to three reasons i.e.

a. It is the easiest and the shortest way of explaining meaning of words and phrases;

b. This method requires few specialized skills on the part of teachers (Brown, 1994);

c. Learners have a few difficulties to understand the lessons since the medium of instruction is the students' mother tongue, which is used to explain conceptual problems and to discuss the use of a particular grammatical structure of a second or foreign language being learn.

From the assessment process point of view, Brown (1994) states that this method is still common in many countries - even popular due to two main reasons i.e. The first, Grammar rules and Translation Tests are easy to construct and can be objectively scored. The second, many standardized tests of foreign languages still do not attempt to test communicative abilities, so students have little motivation to go beyond grammar analogies, translations and other written exercises.

It all sounds rather dull, but it is undeniable to see the facts that the Grammar Translation Method has ever gone through a remarkable success. Bowen (2013) points out that with Grammar Translation Method, millions of people have successfully learnt foreign languages to a high degree of proficiency and, in numerous cases, without any contact whatsoever with native speakers of the language (as was the case in the former Soviet Union, for example).

Now, let's take a look at how the teachers of language who reject The Grammar Translation Method normally convey all they have in mind about the method. It has already been stated in the previous part that Grammar-translation classes are usually conducted in the students' native language. Grammar rules are learned deductively in which students learn grammar rules by rote, and then practice the rules by doing grammar drills and translating sentences to and from the target language. More attention is paid to the form of the sentences being translated than to their 
content. There is not usually any listening or speaking practice, and very little attention is placed on pronunciation or any communicative aspects of the language. The skill exercised is reading, and then only in the context of translation.

Based on the facts, they then claim that what the method is good at is to teach about language, but not to teach language. this actually means that GTM is only good at teaching language rules and will never be good at teaching language skill such as speaking and listening (Bahar. K, 2013), the method typically creates a teacher-centric classroom which means teacher dominates all activities in the classroom from explaining the lessons to correcting the students' errors, the lessons provide no opportunity for speaking practice, learning tedious grammar rules and long lists of vocabulary does not prepare students to communicate in real-world situations. According to Bahar, A. K (2013), learning English may not be viewed as a process of mastering language rules, which is merely focused on making correct sentences of English, but it also has to be seen as a process of developing fluency by involving functional and social dimensions of English.

The complaints related to the method of GTM have generated criticism of the method among other things:

a. The Grammar Translation Method may make the language learning experience uninspiring and boring;

b. The Grammar Translation Method may also left the students with a sense of frustration when they travel to countries where the studied language is used (they can't understand what people say and have to struggle mightily to express themselves at the most basic level);

c. This method neither approaches nor encourages the students' communicative competence therefore students might be able to read and write in English, but would never have the skills required for holding a conversation.

In other words, the complaints try to show us how this method considered to be very rigid and has removed any creativity from the classroom interactions, rendered the class very dull and boring for most students in the class. Finally, because of this rigidity and lack of speaking practice, it is blamed for the students' inability to communicate in which with this method, students may well understand the written language well, but have absolutely no working knowledge of English. For these reasons, this method has nearly been eradicated from English classrooms around the world (Lake, 2013). 
The question to answer now, is the Grammar Translation Method (GTM) really that bad that many language teachers really 'hate' it and need eradicating it from the classroom of language program? The next part of this book will make effort to explore the positive aspects of The Grammar Translation Method and use the principles of GTM as the basis for proposing an alternative point of view which is more positive on this old method. In the end, we could patiently avoid stating that the Grammar Translation Method is an old method which was originally used to teach dead languages. Instead of the statement, we could intelligently say that the grammar translation method is a well-established method which has long been used to teach some of the world's great languages (Seeroi, 2012).

\section{The Communicative Grammar Translation Method}

This section presents a discussion on the Communicative Grammar Translation Method as an innovative step to employ the teaching principles of The Grammar Translation Method in enhancing the students' communication skills when learning a second or a foreign language e.g. English.

\section{Promoting Communicative Skills}

If we review present arguments that many language practitioners address upon the structural list Grammar Translation Method nowadays, we will see that most of them are negative and see GTM as a harmful method, especially when dealing with students who are at the beginning of their learning process of a second or foreign language. They even don't think to put space for GTM in the approach and method they have been following. Besides, some linguists also propose their arguments which presumably account for the failure of the "grammar-translation" method in language pedagogy as well, for example:

1) Rivers, and Temperly, (1978) claim that the use of first language in language learning inhibits thinking directly in the target language which may hinder the development of the ability to think directly in the new language;

2) Gass.S.M, and Selinker, (1992) believe that too much reliance on the first language will result in the fossilization of an interlanguage;

3) Modica, G. (1994) states that the use of the first language wastes too much valuable class time that would be better spent on the target language. This is sometimes referred to as the time on task argument. 
In order to strengthen out the arguments, it is essential that we tackle the practice and theory of translation as the fundamental procedure within the principles of the grammar-translation method. Some scholars claim that today, there are still so many teachers who defend the practice of translation in the context of their language programs not as a means but as a strategy to form students able to become more independent and better equipped when using a foreign language. From those teachers, the scholars then have positive perspectives in mind which enable them to say that the use of translation can bring benefits for both teachers as well as learners, such as:

1) Translation enables the learners to practice and skills (grammar and vocabulary) essential to communicate accurately, meaningfully and appropriately;

2) Translation can be used by the teachers to promote interaction among their learners because the learners involve the negotiation of some possibilities of language forms and meanings;

3) Translation activities can help the learners to interpret, negotiate and express meaning from different perspectives, according to the context and its different interpretive communities (Fish, S.E. 2003);

4) Translation practice can give the students an illustration on language usage and the exchange of different points of view, as well as raising language awareness;

5) If we look back to see how translation activities implemented in the structuralism period, Unfortunately, it was always seen as a means of learning grammatical rules and as a mere exercise of translating or interpreting the words, phrases as well as sentences between the target language and the native language which was aimed at developing students' reading ability to a level where they can read literature in the target language.

Luckily, some poststructuralist scholars have written and rethought about translation in their works based on their experiences using translation in their EFL classrooms which have also brought more positive perspectives on translation. Alan Duff (1999), for example, states in his work that:

"We all have a mother tongue, or first language. This shapes our way of thinking and to some extent our use of the foreign language (pronunciation, choice of words, tone, word order, etc). Translation helps us to understand better the influence of the one language on the other, and to correct errors of habit that creep in unnoticed (such as the misuse of particular words or structures)".

Here, Duff sees the linguistic competence as a dual system in which the mother tongue (MT) 
and foreign language (FL) work together in communication. As for him, translation is an activity of many merits and use, leading to discussions and reflections, since there is not a single correct answer, and promoting three essential qualities in the language learning process: accuracy, clarity and flexibility. To carry on the back of Duff's argument, Deller and Rinvolucri (2002) say that the mother tongue is the mother of all the other languages learned by the student. It is through the mother tongue that the other languages are born in the learner's mind. Thus, to eliminate it from the EFL classroom "is like to wean a baby on day one of their life". Moreover, language users start resorting to their translation skills from the very beginning of any learning/acquiring language process even regarding their mother tongue.

Another arguments, which has seen translation as positive activity in EFL classrooms is Tim Bowen's argument. Bowen is a professor and instructor at Embassy-CES in Hastings, England. It is widely recognized that by the 1970's, it was common to believe that to use the mother tongue (L1) in the classroom was a bad thing and everything should be taught in the target-language in order to expose the students to the second language (L2) all the time. However, Bowen (2013) criticizes it in one of his articles he says that this is fine in principle but, as ever, the reality turns out to be somewhat different. While it is perfectly possible to use only English in class, this approach fails to take account of a number of factors. First of all, general recommendation of this type tends to originate in the world of the multi-ethnic language class in an English-speaking environment. In this situation it is not only desirable to use English at all times, it is, for the most part, essential, given the mixed linguistic background of the learners.In the article, Bowen still goes on discussing the right or wrong use of the mother tongue in mono lingual classrooms and ends up stating that in many instances the mother tongue can be used to provide a quick and accurate translation of an English word that might take several minutes for the teacher to explain and even there would be no guarantees that the explanation had been understood correctly.

Another constructivist pioneer of translation in foreign language classroom is David Atkinson. D. (1987), he writes that the role of the activities based on translation can help in fluency development. For him, the use of L1 can help students to benefit from activities which, at other times, the L2 should be used. Every time, the learners want to communicate, the mother tongue often determines what the learner wants to say, and this must encourage them to speak in the target-language. Reviewing the works of the scholars who encourage the use of translation practices in the EFL teaching is an effort not only to demonstrate that it is still a useful resource 
to be used judiciously in the classroom, but also to present the facts that there are certain types of learners who respond very positively to a grammatical translation method since it can give them both a set of clear objectives and a clear sense of achievement in their process of learning a second or foreign language. Those learners need the principles of translation to equip them with linguistics competence (language forms and vocabulary) of the target language and the opportunity to relate grammatical structures to mother tongue equivalents. Above all, this type of strategy can give learners a basic foundation upon which they can then build their communicative skills.

As the suggestive considerations, we may not deny that the roles of translation as a strategy in the foreign language classroom are still many: First, it helps students to see the link between language usage and use in which translation brings the students linguistics knowledge to be used in communication. Second, it encourages students to see the similarities and differences between L1 and L2 in terms of language rules phonologically, morphologically, syntactically, semantically, as well as pragmatically. Third, through a comparison of the target language and the students' native language, most language learning difficulties are revealed which will ease the teachers and the students to spot their interaction problems. Finally, by allowing or even inviting students to give different translations to a word, teachers can check comprehension and introduce new vocabulary, and this can be a measurement to the learners' development in learning strategies which give learners autonomy in language learning awareness.

It stands to reason to say that translation should never be overused. It is actually an activity which still has a place in language teaching today. Of course, only if, it is properly designed and used at the right time and with the right students. According to Deller. S., et al. (2002), the mother tongue taboo has been with us for a long time but fortunately now things seem to be changing. I believe that many teachers have continued to use the mother tongue because it is both necessary and effective. However, teachers may well have been using it privately and secretly - and certainly not in front of inspectors or colleagues! So we just add to the guilt feelings that we as teachers are so good at having. The point is, the ideas of poststructuralist scholars on translation should be take into account as great contributions to language teachers in order to contemplate one thing that our students are going to become full citizens in our global and competitive society. They absolutely need all the available tools that we can dispose for their learning improvement specifically in learning English as a foreign language. 


\section{b. Modifying the Old to a New Grammar Translation Method}

Even though, the grammar translation method has received all criticism and negative arguments, but it is undeniable that it has been an indispensable method in English teaching as well as an important step in the process of exploring the students' communicative ability in a nonEnglish environment. A learner cannot be named to have successful communication before owing sufficient mastery of acceptable language rules. In other side, although the communicative method has been widely adopted as the most prominent method applied in language classrooms, however, this method is still faced with some problems related to the different language systems, cultural conventions, learning habits, needs and interests between East and West. Consequently, it cannot be claimed as the most effective method applied and conducted immediately and fully at non-English community. Therefore, we should start thinking about an alignment between the classic teaching method and the modern teaching method by taking into account both methods' advantages to the learners of English.

In this part, the writer intends to show that whatever justification is claimed for the traditional "grammar-translation" method, there's no reason to justify that the grammartranslation method can't be used as a more communicative instrument to teach a second or a foreign language which means to use the more enlightened principles of the Communicative Approach into the systematic approach of Grammar Translation. This combination may be the perfect combination for many teachers and learners. The alignment allows the learners to learn grammar rules and vocabulary, then practice using them in spoken conversation for the remainder because without possessing knowledge of the grammatical basis and vocabulary of a language, it can be argued that the learners are in possession of nothing more than a selection of communicative phrases for basic communication only which will be found very difficult when the learner are required to perform any kinds of more complicated interactions with native speakers in the real life. We can therefore say that combining the best of the "grammar-translation" method with the best of "communicative" methods, will emerge a new, more powerful hybrid which is very much alive and kicking in EFL context when we come into the 21 st century. This method is then called, "The Communicative-Grammar Translation Method".

The previous cautionary discussions obviously illustrate that translation could not be avoided. Cohen et. al. (1996) call the fact as mental translation which is virtually unavoidable. All we have to do now is that the focus of translation has to be changed from passive to be active 
which means the strategy not to translate the word or structure to understand written message, but to translate the word or structure to communicate the word and the structure for establishing the social or functional meaning of certain intended messages. We can now understand better the reason for the failure of the traditional "grammar-translation" method in producing good English speakers. The reasons are mainly caused by the historical forces, techniques designed for one purpose (namely, translating literary and technical, written documents), and this was simply misapplied. The change of the GMT's purpose toward a new and very different goal that is to translate to internalize the learnt vocabularies and grammar for promoting the students' communication skills. It is the most important thing to do since to train students to remain make full use of their knowledge of language and in their own mother tongue will facilitate the learners to communicate in a foreign language. According to Andi. K and Arafah. B (2017), mastering communication skills in a foreign language may not be a part from mastering language components of the language such as vocabulary, pronunciation, and grammar. The mastery of the language components should be carried out by internalizing the language components through translation strategy.

So now, we eventually get ready for formulating the parameters for the proposed Communicative-Grammar Translation Method. It is a "modified translation" method since the emphasis is first on helping the student to understand the language rules and vocabulary, the language rules and the vocabulary are then implemented in translation exercise. The exercise is written in the students' mother tongue in which the students are required to translate the text into the foreign language orally. The text is then discussed communicatively. The features of the combination design can be broken down into four main areas. They can be summarized into the following four tables:

Table 1: the goal of the method,

Table 2: the type of language being translated,

Table 3: the materials used to apply the method

Table 4: the classroom procedures.

As we talk about the goals of this method, it is firstly essential to review the process of implementing GTM and CLT in the classroom context and the linguist's formulation on the two methods features.

\section{GTM in classroom context}


Teachers used the students' native language as a medium of instruction in the classrooms. The lesson is initiated by presenting a chapter in a textbook. The chapter contained a massive bilingual vocabulary list. Grammar rules were explained based on the existing grammars from the texts and presented deductively. The explanation of Grammar normally provided the rules for assembling words into sentences. In order to examine the students' achievement in the lesson, tedious translation and grammar drills would be used. Sentences would be deconstructed and translated. Eventually, entire texts would be translated from the target language into the native language and tests would often ask students to replicate classical texts in the target language. Very little attention was placed on pronunciation or any communicative aspects of the language. The skill exercised was reading, and then only in the context of translation. In GTM, reading and writing are the major focus. Vocabulary selection is based solely on the reading texts used, dictionary study and memorization. In addition, accuracy is emphasized. Students are expected to attain high standards in translation. On the basis of the information, Celce-Murcia (1991) formulate the main features of the Grammar Translation Method are as follows:

a. Classes are taught in the mother tongue, with little active use of the target language;

b. Much vocabulary is taught in the form of lists of isolated words;

c. Long elaborate explanations of the intricacies of grammar are given;

d. Grammar provides the rules for putting words together, and instruction often focuses on the form and inflection of words;

e. Reading of difficult classical texts is begun early;

f. Little attention is paid to the content of texts, which are treated as exercises in in grammatical analysis;

g. Often the only drills are exercises in translating disconnected sentences from the target language into the mother tongue;

h. Little or no attention is given to pronunciation.

\section{CLT in the classroom context}

As the matter of fact, the ultimate goal of the Communicative Language Teaching is to develop what Hymes referred to as communicative competence. This can be carried out by giving classroom activities which involve authentic communication to promote the students communication skills. Giving the learners practice activities designed to stimulate real life communication ability. The concept of learning by doing in CLT is really illustrated in the process 
of learning a foreign language, in which the students are given opportunities to interact with one another and perceiving meanings on their own. CLT principles require students not to simply have knowledge of target language forms, structures, and functions. They must be able to apply this knowledge in negotiating meaning. During the negotiation of meaning, the learners need to learn directly from each other, share information and knowledge they possess no matter whether they missed or misunderstood. Therefore, CLT activities frequently take the form of pair and group work requiring negotiation and cooperation between learners, fluency-based activities that encourage learners to develop their confidence, role-plays in which students practice and develop language functions, as well as judicious use of grammar and pronunciation focused activities.

Based on the pedagogical facts of CLT implementation in the classroom Features of CLT Nunan. D. (1991) determine five features of CLT:

1. An emphasis on learning to communicate through interaction in the target language. There is also an awareness of variation in language use rather than simply attention to the language;

2. The introduction of authentic texts into the learning situation;

3. The provision of opportunities for learners to focus, not only on language but also on the Learning Management process. Communicative tasks are achieved through the language rather than simple exercises on the language;

4. An enhancement of the learner's own personal experiences as important contributing elements to classroom learning. There is an emphasis placed on students' initiatives, rather than simply on teacher- centered directions;

5. An attempt to link classroom language learning with language activities outside the classroom.

\section{RESEARCH METHOD}

This article was written and developed from Library research which involved three main steps used to gather information and to complete this work. The first is the step of identifying and locating relevant information concerning the grammar translation method and the communicative language teaching method. The second is the step of analyzing the underlying features, principles, and procedures of both methods. The third is the step of developing and expressing ideas regarding the fusion and the methodology formulated from the fusion. In order to carry out the three steps, two sources were used i.e. primary and secondary sources. Primary 
sources refer to original works in the form of research reports conducted by researchers, linguists, language teachers, as well as language practitioners which represent original thinking, reports on their findings. On the other hand, secondary sources refer to information written by language experts such as books, online articles, dictionaries, handbooks, as well as reviews.

\section{FINDINGS AND DISCUSSION}

Provided with what has already been discussed above, we can then reformulate the main goals of The Grammar Translation Method and The Communicative Language Teaching into an aligned goal of the two great methods to be a new goal formulation within The Communicative Grammar Translation Method. The formulation of the goals is provided in table one as follows.

Table 1. The goals

\begin{tabular}{|c|ll|}
\hline $\begin{array}{c}\text { Traditional Grammar- } \\
\text { Translation }\end{array}$ & $\begin{array}{l}\text { 1. To be able to read classical texts } \\
\text { 2. To promote language accuracy in writing } \\
\text { 3. To memorize rules and vocabularies }\end{array}$ \\
& $\begin{array}{l}\text { 4. To develop mental discipline and intellectual capacity } \\
\text { Communicative }\end{array}$ & $\begin{array}{l}\text { 1. To be able to communicate in target language } \\
\text { 2. To enhance initiatives in communication }\end{array}$ \\
& $\begin{array}{l}\text { 3. To develop real communication awareness } \\
\text { 4. To promote fluency in speaking }\end{array}$ \\
\hline
\end{tabular}

The combination of the two methods will formulate the following goals:

\section{The Communicative-Grammar Translation Method}

\section{Goal 1: Promoting communicative skills spoken and written in TL}

To make the students able to communicate in spoken and written in target language (English), the teachers must be able apply the fusion of the two methods in the students learning levels. The idea is this; when some new learners decide to learn a new language e.g. English as foreign language, the learners generally don't have sufficient communicative ability in English since they are used to accepting knowledge of language passively from the teacher their previous studying experiences at schools for example in junior or senior high schools. As they are taught with a pure communicative method, they absolutely feel down and then frustrated with English learning. In order to avoid such a situation, it may be a good idea to apply the grammar- 
translation method as the major method at the beginning of the learning level and the communicative method as an aid (they learn English rules and vocabularies and allow them to practice all they have learnt by using communicative activities such as pair works and interview.

When the new learners have already been equipped with sufficient language rules and vocabularies which facilitate them to achieve their communicative skills and it apparently works. So, in the next level of their learning program, the communicative method may take the dominance while the grammar-translation method plays a complementary role.

\section{Goal 2: Promoting language accuracy and fluency in communication}

Basically, the fusion of these two methods is mainly intended to help learners of English developing their language skills in listening, speaking, reading, writing and translation. Students' reading, writing and translation skills are mainly trained in learning texts which are commonly given separately from listening and speaking. However, the language skills are inseparably learnt in this fusion method. The fusion requires teachers to base their teaching on texts. The texts are then used as stimuli for oral communication. The activities are divided into three steps as illustrated in the figure of Communicative Grammar Translation Method Framework.

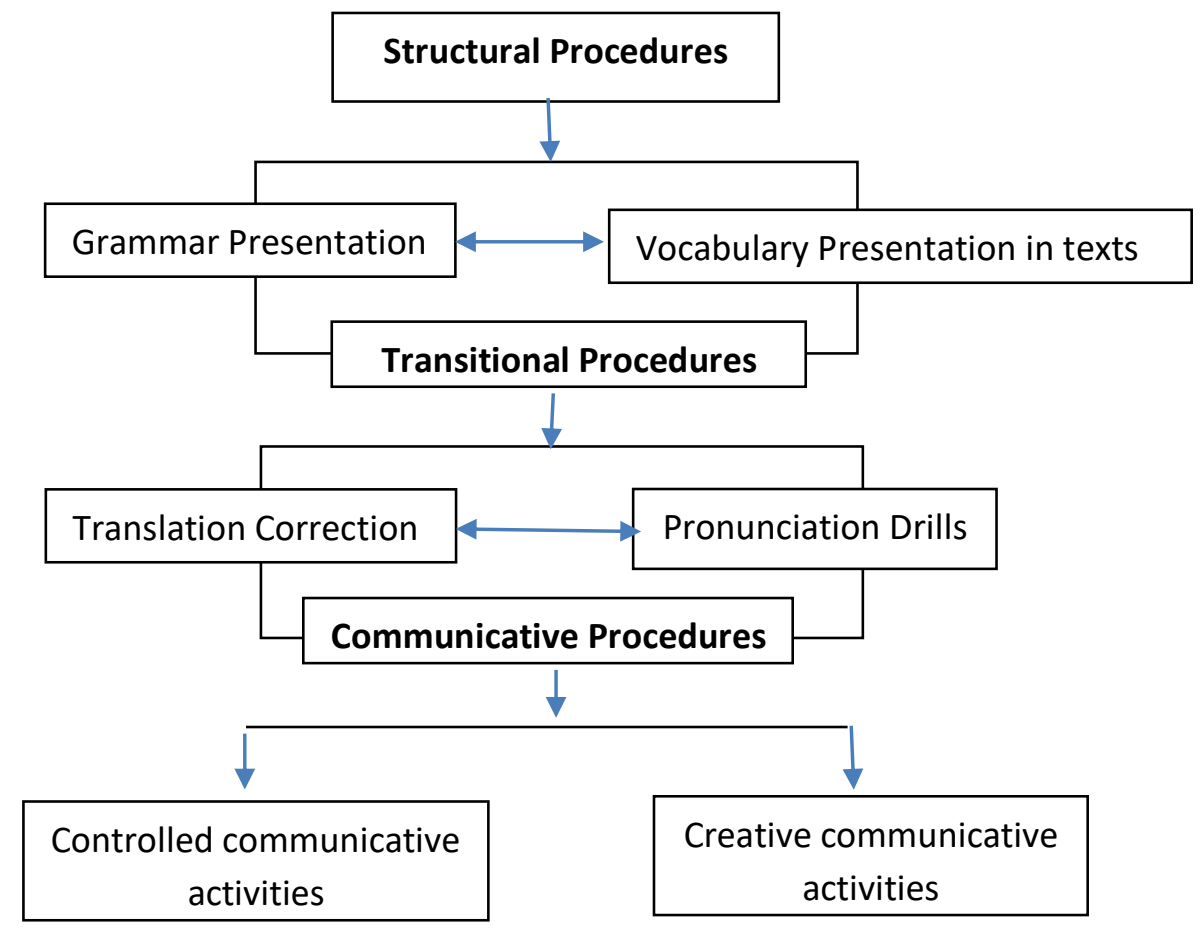

In the framework of The Communicative Grammar Translation Method, 


\section{a. The first step is called structural procedure,}

The teachers give the students certain information of language knowledge by focusing on one particular grammar item e.g. pronouns. The next, the teachers provide a text with a list of new vocabularies of a certain topic (e.g. introducing other people) in the students' native language to be translated into the target language. The sentence structures in the text are primarily focused on the application of the grammar rule that the students have learnt. And then the students have to write their translation. Here, the students have gone through their grammar-translation training and get ready to the next step.

\section{b. The second step is called transitional procedure;}

The teachers initially provide the correct translation on the board and give opportunity to the students to check whether they have correctly translated the text. The students are allowed to ask question related to the incorrect sentences they have. The teachers then get the students to read the correct translation together by imitating their teachers. This is done to drill the students' pronunciation and intonation as well as to practice using the new rule and the new words orally. In this step, the students have taken their knowledge of written language into oral language to prepare them enter into the third step.

\section{The third step is called communicative procedure;}

The teachers get the students to sit face to face in pairs of two or three (e.g. student A and student B). Then, they have to communicate in the context related the text. For example, student A explains the situation from the text (by translated the text from the native language to the target language) while student B is listening and trying to understand A's oral inputs. After that, student $\mathrm{B}$ asks questions about the situation in the text while student A listens and tries to answer all B's questions. In this last step, the teacher must keep on guiding the students to have communication in the context related to the text and help them to solve some problems in key words, sentences and understanding of content they displayed in the previous two steps. When explaining key words and sentences, the grammar-translation method should be used to deepen students' understanding of the text and improve their ability to use language correctly and flexibly through right communication on the text. In the last step, students' enthusiasm for communication is fully encouraged. Here, the step is totally different from that in the previous steps since teachers need to employ a variety of communicative teaching methods to create language situations and communicative tasks which originating from text while going beyond of it. Students are able to 
apply what they have learnt to communicative tasks such as three steps interview, board games, jig saw games, discussions and so on, until the students succeed in achieving the purpose of communicating ideas through language.

\section{a. Goal 3: Using grammar and vocabulary to enhance initiatives in communication}

In communicative grammar translation method, grammar isn't taught merely for studying language rules but for helping students to infiltrate language rules for the sake of developing listening, speaking, reading and writing skills in a better way. For the reason, teachers must be able to present appropriate materials to explain the language system of English according to the students' needs and interests, to provide appropriate texts for translation containing topics which suit the students' experience in their lives, to bring communicative activities and situations for real activities according to students' daily life, to guide students to understand and use grammar correctly in the situations available in the given topics. Therefore, in order to achieve the conditions, this method proposes a four-step technique to teach the students. The technique simultaneously covers explanation, translation, imitation, and application to promote the use of grammar and vocabulary in communication skills.

In the explanation section, the teacher first of all describes a certain grammar rule in the students' native language to minimize difficulties of understanding the lesson introduced by the teacher. Relevant sentences related to the grammar rule are then given as examples of the rule implementation. Exercise is given in the form of translation. The translation is carried out from the students' native language to the target language e.g. from Indonesian (as the native language) to English (as the target language). The exercise is intended for checking whether they have understood the given knowledge points or not. The next is the imitation process which requires the students to have oral imitation of the given text after the text is corrected fit for the given grammatical rule and vocabularies in the previous two steps, here, the teacher needs to provide correct pronunciations of the sentences in the given text to be imitated by the students. It is expected that this process will encourage the students to practice the learnt language systems (grammar and vocabulary) orally for future communicative activities. In the last step, some communicative activities are set to help students to practice using the learnt grammatical knowledge and vocabularies in communication. Once they find that they can apply grammar to real communication and specific tasks instead of memorizing mere grammatical rules, students' learning enthusiasm will be stimulated and their ability of independent communicative skills will 
be cultivated such as skill to explain a certain situation, to address questions, as well as to respond and answer questions.

To sum up, Even though it is the ultimate goal of foreign language teaching to mainly achieve oral communication skill, we may not ignore to involve the most important elements in language that is grammar and vocabulary. Therefore, it is essential that we take into account to still undergo an indispensable stage involving the fusion of the grammar-translation method and the communicative method. As the practitioner of English teaching, teachers need to consider an effort to combine the two great methods (The Grammar Translation Method and The Communicative Language Teaching) to serve the purpose of English teaching that is to make the students' able to communicate effectively in English. The alignment process certainly is in need of considering the needs and the interests of the learners of English.

Table 2. The Types of Grammar Translation

\begin{tabular}{|c|l|}
\hline The Old Grammar- & 1. Word-for-word level \\
Translation & 2. Literary, narrative or technical written text \\
& 3. Formal language \\
& 4. Irrelevant to students' needs and interests \\
& 5. Many infrequent, useless words \\
& 6. Too complex and difficult \\
& 7. Out-of-context (discrete and indigestible) \\
& 8. Lexis of formal composition \\
\hline The New Grammar & 1. Chunked phrase level \\
Translation & 2. Narrative with spoken conversational patterns \\
& 3. Current, colloquial, idiomatic language \\
& 4. Relevant to students' needs and interests \\
& 6. Simple and easy \\
& 7. In-context (Embedded and memorizable) \\
\hline
\end{tabular}

The fusion of the two methods not only presents the change in teaching goals orientation, but also affects the type of language translation. In this new method, the learners are no longer in need of wasting so many hours on trying to master rarely used vocabulary items and translate word by word level, their time would best be spent on trying to grasp the various uses and meanings of relatively high-frequency set of vocabulary items for translating chunk phrases level. This method also requires shifting the literary or technical text to the narrative with spoken 
conversational text to be translated. The contents of the text are not formal language any more, but current colloquial and idiomatic language which are commonly used in real life interaction. The presentation of those types of language translation is expected able to increase the mastery of the high-frequency used words, phrases and structures of the language which can in turn be the most effective solution to the students' difficulty in expressing an immense number of functional meanings for communication.

The above facts definitely indicate that translation may not be avoided in language teaching. Instead, the focus of translation has to be changed from the literary infrequent words or structures to the narrative texts with social and functional meaning of messages which are frequently spoken in communication. Hence, it stands to the reason to say that the old grammartranslation method has widely failed to produce good English speakers not because the method is totally bad. However, misapplication of the techniques which are mainly aimed at translating literary and technical, written documents needs restructuring into more communicative ways.

In addition, the fusion of the communicative grammar translation method and the communicative language teaching can also be seen in the teaching materials context in which the typical features of teaching materials of both methods are integrated to formulate a combination between textual and functional orientation of language activities. The details can be seen in the following table.

\section{Table 3. The Materials}

\begin{tabular}{|c|l|}
\hline $\begin{array}{c}\text { The Grammar- } \\
\text { Translation Method }\end{array}$ & $\begin{array}{l}\text { 1. Explanatory lecture-based, for teacher-fronted presentation } \\
\text { 2. Dull, written-text, reading-based } \\
\text { 3. Textual translation and written exercise } \\
\text { 4. Designed for single student work }\end{array}$ \\
\hline $\begin{array}{l}\text { The Communicative } \\
\text { Language Teaching }\end{array}$ & $\begin{array}{l}\text { 1. Collaborative and student-centered discovery } \\
\text { 2. Interactive and communicative-based. } \\
\text { 3. Functional tasks Dialogue, interviews, discussion, board } \\
\text { games, and jigsaw game. }\end{array}$ \\
& \begin{tabular}{l} 
4. Designed for pair or group work \\
\hline
\end{tabular} \\
\hline
\end{tabular}

The table shows the differences between teaching materials of both methods in general. The alignment of the materials has formulated the following types of teaching materials in the purposed method, among other things: 


\section{1). Explanatory and collaborative materials for students' language mastery}

This proposed method basically employs the basic principles of teaching materials presentation of GTM and CLT i.e. explanatory and collaborative presentations. In the classroom, the teachers are required to begin teaching the students with grammar explanation of a particular rule. The explanation must be carried out in the students' mother tongue. This is done to avoid difficulties in understanding the grammar presentation. A text that contains high frequently used vocabularies and the grammar rule application is then given to the students as an exercise. The text is provided in the students' mother tongue which must be translated into the target language appropriately and correctly. The translated text is then discussed collaboratively between the students. The collaborative discussion is intended to give the students opportunity to practice and finally to master the learnt rule and vocabularies which they can use for future communication.

\section{2). Interactive written text and communicative-based materials}

From here, we can obviously see that the materials are first of all translated for correct forms discovery, then the correct forms are used for functional purposes in communication. The main purpose of translating the text is not to make the students silently understand the use of the grammar rule specifically and the text generally. More than that, the students must use the text as an interactive written text which means to enable the students to use it for communicative activities.

\section{3). Functional translation tasks}

As the students already discover the correct forms of their text translation, the translation has to be practiced communicatively. The teachers can get the students to practice the translation by using three steps interviews technique for instance. In the technique, the teacher splits the students into pairs. The students are assigned to discuss the text by using three steps interview procedures such as:

a. Student A explains the text by using pictures to student B;

b. Student B listens carefully and tries to understand A's explanation;

c. Student B then asks questions about the situation of the text to student $\mathrm{A}$ and student $\mathrm{A}$ must try to answer the questions correctly based on the text.

(Both the pictures and the questions are provided by the teachers).

\section{4). Designed from individual to pair or group work materials}


Volume 4, Number 2, December 2018

To make sure the students' mastery of the rules and vocabularies in the given text, the teachers are required to employ communicative tasks in which all the activities are carried out in pair or group works such as oral presentation, board games, and jigsaw games etc. The activities are expected to give the students more opportunities to communicate all they have learnt from the teachers' explanation on grammar and vocabularies, as well as pronunciation correctly and appropriately. Besides, the activities can also train the students listening comprehension on the application of the rule and vocabulary existing in the translated text.

The effect of the GTM and CLT fusion also occurs in the teaching procedure. The description can be viewed in following table.

\section{Table 4. The Classroom Procedures}

\begin{tabular}{|c|l|}
\hline $\begin{array}{c}\text { The Old Grammar- } \\
\text { Translation }\end{array}$ & $\begin{array}{l}\text { 1. Present-Practice-Comprehend } \\
\text { 2. Teacher input-driven (What we think they should } \\
\text { know) }\end{array}$ \\
& $\begin{array}{l}\text { 3. Teacher-centered lectures } \\
\text { 4. Prepare for written tests }\end{array}$ \\
\hline $\begin{array}{c}\text { The New Grammar } \\
\text { Translation }\end{array}$ & $\begin{array}{l}\text { 1. Present-Practice-Comprehend- Communicate } \\
\text { 2. Teacher input and student-output driven (What they } \\
\text { use to say) }\end{array}$ \\
& $\begin{array}{l}\text { 3. Student-centered pair/group work } \\
\text { 4. Prepare for written and spoken tests }\end{array}$ \\
\hline
\end{tabular}

It is obviously seen that in the proposed method, classroom procedures are presented in four levels namely:

1. The teacher begins the class with grammar. The grammar is presented deductively in which a certain rule is given and then the exercise (Present);

2. A text written in the students' native language is given to be translated in the target language to practice the use of the learnt rule and frequent used vocabulary in a topic (practice);

3. To ensure the students comprehension of the given lesson, the teachers provide the correct forms of the translation and re-explain all the students' difficulty in the lesson (comprehend); 
4. After the correction is given, the students get ready for undertaking communicative activities. The communicative activities will enable the students to communicate anything they understand about the lesson (communication).

The four procedures above illustrate two main activities in the classroom. The first is the teacher's inputs (explanation and correction) and the second is the students' output (translation and communication). In the input part, the teacher makes effort to provide information on what the teacher thinks that the students need to know according to their needs and how to use all they have known correctly and appropriately. In the output part, the students make effort to practice all they have known from the teacher explanation in the form of translated text and communicative activities. In this case, the teacher and the students cooperatively interact in the classroom from explanation to communication. However, another important thing, beside making the students good at communicating in a foreign language, is that the students will be prepared to be good at working on written test and spoken test in their language education career since they are given detailed explanation on how to construct grammatically correct sentences and activities which enable them to practice speaking the sentences.

\section{E. CONCLUSION}

Finally, this paper is expected able to facilitate the attainment of most language teaching goals that is to promote students' communication skills, this communicative grammar translation method is expected to help English teachers to: (1) find a new teaching principle which is adopted from advantages of two great methods (2) understand the details associated with the effect of the fusion in teaching goals, teaching materials as well as classroom activities (3) understand that grammar and vocabulary are the most powerful instruments in language that should be taught at the beginning as a foundation to accelerate the development of communication skill, (4) adopt specific techniques from the lessons samples to make teaching English more effective and communicative through translation approach and (5) know the exact reasons for the English teachers' preference employing the grammar translation method in more communicative ways when teaching. These objectives are for all teachers regardless of where you are teaching or who your students are. 
Volume 4, Number 2, December 2018

\section{REFERENCES}

Andi, K., \& Arafah, B. (2017). Using Needs Analysis to Develop English Teaching Materials in Initial Speaking Skills for Indonesian College Students of English. The Turkish Online Journal of Design, Art and Communication (TOJDAC), Special Edition, 419-436.

Atkinson, D. (1987). The Mother Tongue in the Classroom: A Neglected Resource. ELT journal, 41(4), 241-247.

Bahar, K. (2013). The Communicative Grammar Translation Method: An Integrated Method of CLT and GT for Teaching English Communicatively and Accurately. Yogyakarta: Trustmedia

Bahar, A. K. (2013). The Communicative Competence-Based English Language Teaching. Yogyakarta: Trust Media.

Bowen,T. (2013).Teaching Approaches: The Grammar-Translation Method. Online Article: http:// www.onestopenglish.com.

Brown, H.D.(1994). Principles of Language Learning and Teaching. Englewood Cliffs, PrinticeHall: New Jersey.

Celce-Murcia, M. (Ed.) (1991). Teaching English as Second or Foreign Language. Newbury House Boston.

Cohen, Andrew D. and Hawras, Steve (1996). Mental Translation into the First Language During Foreign-Language Reading, The Language Teacher, Vol.20, No.6

Deller, S. Et al. (2002). Using the Mother Tongue - Making the Most of the Learner's Language. 1st. ed. Delta Publishing: London.

Duff, A. (1996). Translation. 5. ed. Oxford University Press: Oxford.

Fish, S. E. (2003). Is There a Text in This Class? - The Authority of Interpretative Communities. 12 ed. Harvard University Press: Cambridge, USA.

Gass, S. M., \& Selinker, L. (Eds.). (1992). Language Transfer in Language Learning: Revised edition (Vol. 5). John Benjamins Publishing.

Lake,W. (2013). The Grammar-Translation Method of Teaching English. Online Article: http://blog.about-esl.com

Modica, Guy (1994). Native Language in the Second Language Classroom, Bulletin of the Faculty of Commerce, Nagoya University of Commerce and Business Administration, V.38, No.2

Morris, S. (1996). Viae Novae: New Techniques in Latin Teaching. London: Hulton Educational. 
Nunan, D. (1991). Communicative Tasks and the Language Curriculum. TESOL Quarterly, 25(2), 279-295.

Orrieux, C. (1989). Jews and Godfearers at Aphrodisias. (Proceedings of the Cambridge Philological Society. Supplementary Volume 12).

Richards, J. C. Rodgers,T.S. (2001). Approaches and Methods in Language Teaching. Cambridge University Press: Cambridge UK

Rivers, W. M. and Temperley, M. S. (1978). A Practical Guide to the Teaching of English as a Second or Foreign Language. New York, NY: Oxford University Press.

Seeroi,K.( 2012). The grammar-translation method: Is it really all that bad?, Online article: http://www.japantoday.com 